\title{
Organization of Accounting in Fur Farming according to IAS
}

Klychova G.S.

\author{
Kazan State Agricultural University Kazan, 420015, Russia \\ Kazan Federal University, Institute of Management, Economics and Finance, Kazan, 420008, Russia
}

Kulikova L.I.

Kazan Federal University, Institute of Management, Economics and Finance, Kazan, 420008, Russia

Mavlieva L.M.

Kazan State Agricultural University Kazan, 420015, Russia

Klychova A.S.

Kazan State Agricultural University Kazan, 420015, Russia

\section{Doi:10.5901/mjss.2014.v5n24p84}

\begin{abstract}
The article deals with biological assets accounting in accordance with International Accounting Standard (IAS) 41; a list of physical indicators of organization activities for each group of biological assets, tabular presentation of information about the fair value of agricultural products and biological assets, as well as about the profits and losses in fur farming are offered. The data and arguments mentioned above show the possibility and a clear line of reporting in the field of fur farming in accordance with the requirements of IAS 41.
\end{abstract}

Keywords: fur farming, biological assets, International Accounting Standard (IAS) 41, fair value.

\section{Introduction}

In today's conditions of economic crisis the enterprise management presents a complex problem. In this situation, there is a need in timely (daily, hourly) information for management decisions making. One of the main criteria for efficient management is the effective use of financial, material and human resources. Managerial accounting forms essential mechanism for this, while allowing fully solving problems of planning, accounting of certain activities, regulation and monitoring. But at the same time there is a problem of developing of such a system of management accounting, in which this mechanism would work efficiently. In this case, one can use the principles and concepts of accounting in developed countries, namely International Accounting Standards (IAS), which include methodology, technology, financial apparatus, well-developed forms of financial reporting used for management. These standards oriented to specific users are based on the criteria of usefulness of financial information for economic decision-making. Therefore, the same data are useful for making management decisions. Due to specifics of agricultural organization activities for management purposes it is advisable to use IAS 41 "Agriculture", which defines agricultural activity as a "business management process of biological transformation of biological assets for sale, agricultural products obtaining, or additional biological assets producing." In the Russian Federation, the developed drafts of normative documents for accounting of biological assets can be used: draft regulation on accounting "Accounting of biological assets"; comments on the draft on accounting "Accounting of biological assets"; draft guidelines on primary use of regulation "Accounting of biological assets."

\section{Theory}

IAS 41 defines agricultural activity as management of biological transformation of animals and plants (biological assets) in order to implement, obtain agricultural products, or produce additional biological assets. Fur farming in accordance with IAS is a sub-sector of agriculture, engaged in management of biological transformation of fur animals in 
order to implement the farmed products (live animals, skins, meat and manure), get farmed products (skins, meat and manure) or get additional number of animals (progeny obtaining).

IAS 41 establishes order of biological assets accounting during the period of growth, degeneration, production and reproduction, as well as the order of agricultural products initial assessment at the point of their collection.

With regard to fur farming, IAS establishes the accounting treatment of fur animals (rabbits) during growth of young animals; degeneration - mortality, poor development, diseases, mechanical damage of the fur of live animals, etc.; production in fur farming, which partly coincides with growth of animals, in another part the production concerns the offspring of fur-bearing animals. The accounting treatment for production in this case refers specifically to the offspring. The reproduction also concerns the offspring of animals. The requirement of IAS 41 to evaluation of animals from the time of initial recognition and until the beginning of slaughter: the assessment should be carried out at fair value less estimated point-of-sale costs, except in cases, where at the time of initial recognition the fair value cannot be determined with sufficient reliability.

IAS 41 regulates the issues of state subsidies of agricultural activity.

According to IAS 20, "government subsidies are state aid in the form of transfers of resources to a company in return for compliance in the past or in the future to certain conditions relating to the operating activities of the company. The state subsidies do not include such forms of government assistance which cannot be reasonably estimated, as well as such transactions with the state, which do not differ from the normal course of trade". The government grants have one special feature - different conditions for granting subsidies can be set in each case.

In this regard, IAS as a whole (in particular, IAS 20 and IAS 41) does not focus attention on the possible conditions for granting subsidies. The main emphasis is made on the time of recognition of subsidies accounted for, namely, for the moment of recognition of the subsidy is taken the moment, when the grant becomes subjected to the receipt.

IAS 41 should be applied in the process of accounting for the following objects of fur farming in the cases, where they relate to agricultural activity: adult fur-bearing animals and rabbits, fur-bearing animals and rabbits for breeding, the offspring of fur animals and rabbits - as the biological assets; adult fur animals and rabbits at the time of slaughter, raw skins, raw meat of animals at the time of its getting, manure at the time of its getting - agricultural products at the time of its collecting; government subsidies for fur farming (rabbit farming) of both federal and subjects of the Federation.

The process of killing and removing the skins, as to its meaning, corresponds to the process of harvesting, the order of which is determined by IAS 41.

IAS 41 defines the collection of agricultural products as "detachment of products from biological asset or cessation of life of biological asset ". The process of killing and removal of skin is usually called the slaughter of animals, in this regard, the process of harvesting in accordance with IAS 41 for fur farming should be considered as the slaughter of animals. In domestic practice of fur farming, there is a clear division between slaughtering and primary processing of skins. In this regard, the primary processing of skins is already related to the processing of agricultural products in terms and concepts of IAS 2.

According to IAS 41 "biotransformation consists of processes of growth, degeneration, production and reproduction, resulting in qualitative or quantitative changes in a biological asset" and "Group of biological assets is a set of similar animals or plants".

The group of "homogeneous" biological assets should include fur-bearing animals and rabbits as technologically and historically developed sub-sector of human activity.

IAS 41 regulates the issues of accounting and reporting of only process of artificial breeding of animals and rabbits and does not address obtaining products of fur-bearing animals as a result of trade - the collection as a result of hunting. With regard to fur farming, biotransformation of fur animals consists of the processes of growth, degeneration and reproduction, resulting in quantitative and qualitative changes of fur-bearing animals.

The degeneration according to IAS 41 is defined as "a decrease in the number of animals and plants or deterioration of their quality characteristics." Degeneration for fur farming is a potential deterioration of skins of animals as a result of disease or mechanical damage to the body of animal or reduction in the number of animals due to mortality. As a result, recitation or decrease in fair value of potential skin occurs. Valuation issues of farming products obtained in conditions of degeneration are fully regulated by IAS 41.

To determine the financial result, IAS 41 requires the implementation of procedures for recognition and assessment of a biological asset, as well as products obtained from biological asset.

With regard to fur farming, IAS 41 in paragraph 10 determines that a company should recognize a biological asset - live fur-bearing animals or agricultural products - raw materials and carcasses when:

1. The company monitors the asset as a result of past events. It is about getting the offspring of fur animals at the farm and its growth. Also the live fur-bearing animals may be acquired - in this aspect, they are also accepted 
for admission according to this requirement. Since in this paragraph is mentioned just the asset, regardless of whether it is biological or otherwise, under its requirements fall raw pelts of fur-bearing animals and carcasses produced on the farm or taken from the public and other producers for further processing and sales.

2. There is a likelihood of company's future economic benefits from the asset. Here we are talking about the concepts of products and goods. In fur farming, the products are raw skins and carcasses of animals, the commercial products are also raw skins and carcasses of animals. However, for agriculture, as it is known, the concept of level of marketability is characteristic one, which shows the share of products for sale in the total volume of products. That part of products manufactured, which is due to technological reasons will not be directed to the sale, and will be used for other purposes, which, in turn, will contribute to the production of additional marketable products - getting future economic benefits must still be recognized for accounting in accordance with the requirements of this item of IAS 41. Such products may include the carcasses of animals that will serve as feeding stuff for animals, nutria carcasses sent to the canteen of the company for preparation of meals paid, natural payment in the form of fur farming products. Fur farming products do not covered by this item, they are consumed in the company for personal use without payment. This could include a free lunch (prepared only from the carcasses of rabbits and nutria), free distribution of carcasses (to workers, villagers, etc..), raw skins of animals, intended to be used as gifts, i.e. everything, that in no way attracts the potential investors because does not give direct future economic benefit (although these positions may be considered as expenses of the organization).

3. Fair value or cost of the asset can be evaluated reliably. If it is impossible to determine the fair value, domestic regulatory and methodological framework, in case of its compliance and maintaining appropriate records, adjusted to the requirements of IAS 41, makes it possible to determine on a reasonable basis the cost of furbearing animals and products of fur farming. Algorithm for estimating the offspring of fur animals at initial recognition. If it is possible to sell the pelt of a newborn puppy of this type of fur-bearing animals, then these puppies should be valued at the last price of the transaction or at the announced price for such a skin on the market plus the price for the sale of the puppy carcass less estimated selling expenses. Puppy carcass can be evaluated at the price of similar products purchased by the company for food of fur-bearing animals, for example, chicken carcasses. If one cannot sell the skin due to lack of physical qualities of the skin (small size, weak pubescence, etc.) and, consequently, lack of market, the puppies should be valued at standard cost less accumulated depreciation and any impairment losses.

The standard cost in this case is calculated as $50 \%$ of expenditures (excluding depreciation) for maintenance of the whole herd of young animals of this species to the point where the physical parameters of the puppy already allow the use of its skin for sale divided by the number of puppies. The amount of expenditures is taken on the basis of historical data corrected for inflation. The moment of costing when the physical parameters of the puppy already allow the use of its pelt for sale must be considered fundamental in contrast to the method proposed in the national guidelines.

By the end of production cycle of fur animals growing at the time of slaughter the skins in any case must be evaluated at fair value. According to IAS 41, regarding the production of fur farming (agricultural products) assessment should be carried at fair value established at the time of animals slaughtering (harvest) less the estimated selling expenses. Such estimation is the cost of production of fur farming as of the date when application of IAS 2 "Inventories" begins. Based on the technology of slaughter the date of collection of fur farming products (crop) and the date of application of IAS 2 "Inventories" should be considered as coincident.

To facilitate the determination of fair value IAS 41, paragraph 15 provides guidance: "The fair value of a biological asset or agricultural product is easier to define, if to group the biological assets or agricultural products according to background characteristics, such as age or quality. The company chooses the basic characteristics on the basis of those used in the market as the basis for pricing".

Fur farming is characterized by the following group of products: by type of animals: mink, sable, arctic fox, fox, etc.; by color attributes, for example, minks have the following color groups: brown, mahogany, pastel, light brown, pearl, palomino, white, silver, blue, sapphire, black corduroy etc.; by size, in different fur exchanges there are various approaches to estimating the size; by quality.

According to IAS 1, paragraph 54, information about the value of biological assets should be reported in the balance sheet as a separate line.

IAS 1, paragraphs 66 and 67, permit (commit) the division of the article "biological assets" into subclasses or in balance, or in the notes to the balance sheet. In reporting of organizations involved in fur farming, it is advisable to allocate at least two sub-items: the value of biological assets - fur and rabbit farming; the value of biological assets - other branches of agriculture. Such division of articles of biological assets is significant for potential consumers of information 
about activities of organization dedicated to fur farming, since it clearly separates value of biological assets related to fur farming and the value of biological assets related to other branches of agriculture, which the organization is engaged in.

\section{Results}

IAS 41 does not provide accurate list of groups and classification features of biological assets, leaving this procedure to organizations. In this case, the organization must disclose the principles underlying the classification used. We recommend the groups of biological assets for fur farming, as to which it is necessary to form information in financial accounting prepared in accordance with IAS.

Table 1: Groups of biological assets for fur farming presented in accordance with IAS 41

\begin{tabular}{|l|c|c|c|c|c|c|}
\hline \multicolumn{2}{|c|}{ Kinds of biological assets } & Groups of assets of fur farming & \multicolumn{4}{|c|}{ fur animals groups as to types } \\
\hline \multirow{3}{*}{ Mature } & Bearers & main herd & Mink & Fox & Arcticfox & Sable \\
\cline { 2 - 7 } & \multirow{2}{*}{ Consumed } & Animals for slaughter & Mink & Fox & Arcticfox & Sable \\
\cline { 2 - 7 } & & Sperm & Mink & Fox & Arcticfox & Sable \\
\hline Not mature & $\mathrm{X}$ & Foals in growing & Mink & Fox & Arcticfox & Sable \\
\hline
\end{tabular}

In paragraph 46, IAS 41 establishes the requirement about disclosure of positive performance of organizations for each group of biological assets. With regard to fur farming it is necessary to disclose physical indicators shown in table 2. This list of physical indicators is essential and largely determines cost valuations in fur farming industry, both current and projected ones, which is important for consumers of financial accounting prepared in accordance with IAS.

Table 2: Physical indicators of fur farming disclosed in accordance with IAS 41

\begin{tabular}{|c|c|c|c|}
\hline \multirow{3}{*}{$\begin{array}{l}\text { Groups of physical } \\
\text { indicators }\end{array}$} & \multicolumn{3}{|c|}{ Physical indicators } \\
\hline & Mink & Arctic fox & Sable \\
\hline & \multicolumn{3}{|c|}{ biological assets } \\
\hline Main herd & \multicolumn{3}{|c|}{ livestock, total mass, mode of mass, color groups, type of hair (long, short) } \\
\hline Animals to slaughter & \multicolumn{3}{|c|}{ livestock, total mass, mode of mass, color groups, type of hair (long, short) } \\
\hline $\begin{array}{l}\text { Young animals in } \\
\text { growing age }\end{array}$ & \multicolumn{3}{|c|}{ Age, livestock, total mass, mode of mass, color groups, type of hair (long, short) } \\
\hline \multicolumn{4}{|l|}{ Agricultural products } \\
\hline Sperm & \multicolumn{3}{|c|}{$\begin{array}{l}\text { Number of pellets or polypropylene straws with their volume in milliliters and the estimated number } \\
\text { of motile sperm cells after thawing. }\end{array}$} \\
\hline Crude skin & \multicolumn{3}{|c|}{ Number of units divided into color groups and type of hair (long, short) } \\
\hline Carcasses & \multicolumn{3}{|l|}{ Food and feed (amount in centers) } \\
\hline Manure & \multicolumn{3}{|l|}{ Quantity in tones } \\
\hline By-product (fat etc.) & \multicolumn{3}{|l|}{ Quantity in centers } \\
\hline
\end{tabular}

When correlating mode of mass with average value of mass of fur animals, one can judge on uniformity of herd and thus, more objectively to evaluate the health of animals and predict future cash flows. In addition, mode is more objective measure than the arithmetic mean. Its inclusion is due to the fact that it is necessary to assess the nutritional state of animals, and in this case for all sex and age groups. This is the important indicator, since, for example, for broodstock the excessive fatness and underweight greatly determine fertility, and for animals in growth fatness determines the potential size and quality of skin, which the price depends on.

Based on the requirements of paragraphs 40 and 48, according to IAS 2, tabular representation of the fair value of agricultural products and biological assets, as well as the financial results in terms of fur farming will be as follows. 
Table 3: Fair value, profits and losses of fur farming (fragment of report on financial results for fur farming, drawn up in accordance with the requirements of IAS 41 and IAS 2 for quarter of $20 x x$, ths, rub.

\begin{tabular}{|c|c|c|c|c|c|c|}
\hline \multirow{2}{*}{ Indicators } & \multirow[t]{2}{*}{ Line code } & \multirow{2}{*}{$\begin{array}{l}\text { At the } \\
\text { beginning of } \\
\text { the period }\end{array}$} & \multicolumn{2}{|c|}{$\begin{array}{l}\text { movement of cost for the } \\
\text { current period }\end{array}$} & \multirow{2}{*}{$\begin{array}{c}\text { At the end } \\
\text { of period }\end{array}$} & \multirow{2}{*}{ Change } \\
\hline & & & $\begin{array}{l}\text { income } \\
\text { (growth) }\end{array}$ & $\begin{array}{l}\text { expenditure } \\
\text { (decrease) }\end{array}$ & & \\
\hline $\begin{array}{l}\text { Fair value } \\
\text { total }(2110+2120+2200+2210+2220+2230+2240)\end{array}$ & 2100 & 49539 & 103043 & 37663 & 114919 & 65380 \\
\hline Of main herd & 2110 & 19992 & 0 & 157 & 19835 & -157 \\
\hline young in growing & 2120 & 29397 & 83119 & 19506 & 93011 & 63613 \\
\hline of them slaughtered total $(2131+2132)$ & 2130 & 0 & 19573 & 19573 & 0 & 0 \\
\hline including adult animals & 2131 & 0 & 157 & 157 & 0 & 0 \\
\hline young & 2132 & 0 & 19416 & 19416 & 0 & 0 \\
\hline fair value of pelts & 2200 & 0 & 18447 & 18000 & 447 & 447 \\
\hline Carcasses obtained & 2210 & 1195 & 1127 & 0 & 2321 & 1127 \\
\hline Of Manure & 2220 & 150 & 350 & 0 & 500 & 350 \\
\hline deaths & 2230 & (10) & (90) & 0 & $(100)$ & 90 \\
\hline sperm & 2240 & 0 & 0 & 0 & 0 & 0 \\
\hline $\begin{array}{l}\text { Sales of raw skins (revenue, profit) total from the } \\
\text { beginning of the year }\end{array}$ & 2300 & 20100 & 18000 & $X$ & 38100 & 18000 \\
\hline Expenditures (total cost) & 2400 & 18150 & $\mathrm{X}$ & $\mathrm{X}$ & 37950 & 19800 \\
\hline $\begin{array}{l}\text { Estimated marketing costs on the sale of assets } \\
\text { related to line } 2100\end{array}$ & 2410 & 4000 & 1004 & 4 & 5000 & 1000 \\
\hline $\begin{array}{l}\text { Profit according to IAS } 41 \\
(2100+2300-2400-2410)\end{array}$ & 250 & 48684 & $X$ & $X$ & 111263 & 62580 \\
\hline $\begin{array}{l}\text { Profit according to Russian accounting standard } \\
(2300-2400)\end{array}$ & 260 & 1950 & $X$ & $X$ & 150 & -1800 \\
\hline
\end{tabular}

The information in this table reflects the schematic representation of the statement of financial performance in fur farming drawn up in accordance with IAS 41 and IAS 2. However, this scheme has a practical value and can be used in preparing financial accounting in accordance with IAS unchanged, respectively, adding the accounting data on other areas of the organization.

Let us consider Table 3 line by line.

Line 2100 reflects the fair value of minks of all age groups based on the fair value of skins, carcasses, manure and cost of cattle loss, from which it is impossible to obtain the potential revenue (fallen animals, from which there is no way to get skins and carcasses suitable for further use). In lines from 2110 to 2130 the fair value is reflected in accordance with IAS 41, based on the fair value of live animals (plus the cost of the skins of carcasses) and sperm. Expenditure in lines 2120 and 2130, column 5, is the cost (in fair evaluations) of live animals going to slaughter, and unused cattle loss. Correspondingly, these figures form the data as to lines from 2130 to 2131 and line 2230 column 3.

In lines from 2130 to 2132 the fair value of slaughtered animals is reflected. It should be noted here that the value of slaughtered animals includes in sum the fair value of skins and carcasses.

Lines 2131 and 2132 decrypt line 2130.

In line 2230, "Mortality" the value of mortality is shown, provided that it is impossible to use the carcasses and skins of dead animals. In table 3 , in line 2230, column 5, further movement of the value of mortality is not shown in order to maintain the consistency of formation of column 6 . In practice, this cost is included in expenditures and in the above calculations is also taken into account in the expenditure.

In line 2200 there is reflected the income of animals skins in stock at the cost of 18,447 thous. rubles (column 4), which is calculated as difference between the value of slaughtered mink (line 2130 column 5) and the value of carcasses (line 2210 column 4). Also in line 2200 is reflected the expenditure (column 5) of skins from reserve to implementation at cost of 18,000 thous. rubles. The result is that in store is left the amount of skins for 447 thous. rubles (column 6 ), which passes into the following periods.

It is necessary to take into account that the estimated fair value of sales sent to the reserve and attributed to the cost, in Table 3 is made according to prices at the moment of time, relating to the end of _ quarter of 20xx. In other words, the table takes into account the principle of revaluation of assets at the time of reporting, nominated in accordance with IAS. 
Line 2300 reflects the proceeds from the sale of skins, cumulative from the beginning of the year at the beginning and the end of period, as well as the current period. In this line the estimation of the fair value corresponds to IAS 18.

Proceeds from the sale of manure and carcasses may also be present, which should be reflected appropriately in this report. However, in the conventional example, these products are not implemented to the side, so revenue from it is not reflected, but in lines 2210 and 2220 the fair value is simply shown. Lines 2210 and 2220, column 5, do not show further movement of value of carcasses and manure in order to maintain the consistency of formation of column 6.

In practice, the carcasses completely go to be eaten by animals, and their cost is included in the full cost of products of farming (included in line 2400). In the analysis it should be taken in mind that the cost of carcasses presents in the valuation of live animals and deduction of the total cost from the fair value of fur-bearing animals, in which is also present the value of carcasses, we have mutually compensating values. From economic point of view, this means savings on feed of its own production.

In line 2400 the full costs associated with growth and sale of minks are reflected. In this example, we do not concentrate on registering the report on profits and losses in the accepted format, focusing on IAS 41 and IAS 2. Therefore, the known articles of expenditures (depreciation, administrative expenses and so on.) are not mentioned in Table 3.

The line 2410 reflects the expected marketing costs associated with possible sale of all assets of mink farming. This item is included on the basis of requirements of IAS.

Line 2500 reveals profit according to the requirements of IAS as the sum of the fair value of minks (sperm, adult animals and young), skins left, manure, carcasses and raw pelts sold minus the total expenditures.

For comparison the line 2600 reveals profit according to Russian accounting standards as the difference between the proceeds from the sale of raw skins and full expenditures.

The form of Table 3 brings together a number of possible reporting forms, which should clarify the statement of profits and losses of fur farming industry, which follows from IAS, in general, and IAS 41, in particular. Columns "income" and "expenditures" of Table 3 are intended to make clear changes in the fair value of the assets of fur farming at the end of the reporting period compared to the beginning of the period, so they are given in the table. In practice, the movement of cost for the period may be reflected in a separate report form similar to that shown in Table 3.

The data and arguments mentioned above show the possibility and a clear line of reporting in the field of fur farming in accordance with the requirements of IAS 41.

\section{Conclusions}

In the current economic environment, both external (financial) and internal accounting reporting are the main sources of information for assessing the solvency and creditworthiness of potential business entities, management decision-making in evaluation and optimization of structural units, business processes, and other segments of agricultural organization.

Using this information in the field of supply, the selection of suppliers and contractors is made, the ways of transporting and delivery of raw materials, components, semi-finished products to the organization and directly to the production units are determined. Biological assets from the investor's perspective as a user of accounting data require special user skills, that is, the rules of evaluation and recognition in reporting, in view of their special economic function as a property that cannot serve as collateral for obligations of the company, when its financial position corresponding to the principle of continuity of operations, but for this it is a major potential of profitability of appropriate enterprises. On this basis, a possible way to improve the content of accounting reporting in Russian agricultural enterprises should be adaptation of method of biological assets accounting, determined by international accounting standards, with a view to the possibility of its use in Russian accounting practice.

\section{References}

Alborov R.A. Accounting for biological assets at the fair value in accordance with IAS 41 "Agriculture" / R.A. Alborov, S.M. Kontsevaya, E.V. Fastova // Economy of agricultural and processing enterprises - 2007. - №1. - P. $33-39$ (in Russian)

Vakhrushina M.A. International Accounting Standards: textbook / M.A. Vakhrushina // M .: Read Group, 2011 - 656 p. (in Russian).

Klychova G.S, Expenditure accounting and calculation of fur farming production cost / G.S. Klychova, A.R. Zakirova, A.S. Klychova Kazan: Center for Innovation Technologies, 2012 - 156 p. (in Russian).

Klychova G.S. Accounting for financial results of agricultural organizations in accordance with IAS / G.S. Klychova, M.M. Zalaltdinov, M.A. Zyabbarov. - Kazan: Kazan University Press, 2005 - 159p. (in Russian) .

Kozmenkova S.V. Features of application of IAS 41 "Agriculture" in Russian practice of Accounting and Reporting / S.V. Kozmenkova, E.N. Shatina // International accounting. - 2010. - № 16 (148). - P. 2-7. (In Russian) . 
International Accounting Standards. - M .: Askeri-ACCA 2011.- 998 p. (in Russian).

Pyatov M.L. Accounting of agricultural products and disclosure of information formed in accordance with IAS 41 / M.L. Pyatov and I.A. Smirnova [electronic resource]. - Mode of access: http://www.buh.ru/document-1522 (in Russian)

Safiullin L.N., Klychova G.S., Nizamutdinov M.M., Mavlieva L.M. Priorities of agricultural credit cooperation development. Mediterranean Journal of Social Sciences.- Vol.5, No18, (2014)-pp. 215-218.

Klychova G.S., Zakirova A.R., Klychova A.S., 2012. Features calculation of production of fur farming. Bulletin of Kazan State Agrarian University, № 3 (25), P. 20-26.

Gabler. Wirtschafts-Lexikon, Auflage, 1988 Betriebswirtschaftlicher Verlag Dr. Th. Gabler GmbH, Wiesbaden. 